\title{
SF-36 QUESTIONNAIRE AS THE INSTRUMENT OF THE LIFE QUALITY ASSESSMENT IN PATIENTS WITH DIABETES MELLITUS TYPE 2
}

\author{
T.A.Germanyuk, T.I.Ivko \\ National Pirogov Memorial Medical University \\ Key words: diabetes mellitus; quality of life; pharmacotherapy; SF-36 questionnaire
}

\begin{abstract}
Today diabetes mellitus (DM) significantly reduces the parameters of the life quality of patients. Therefore, the life quality assessment is current and promising direction of medicine, which allows to determine a reasonable method of treatment. The aim of this study was the use of SF-36 questionnaire for determining the quality of life of patients with T2DM when applying different schemes of pharmacotherapy. The research objectives are: 1) carrying out retrospective analysis of medical histories and treatment sheets of T2DM patients in hospital environment; 2) carrying out frequency analysis of the treatment regimens used; 3) analysis of patients included in the study; 4) carrying out the survey by a nonspecific SF-36 questionnaire; 5) determination of the quality of life in T2DM patients. The research object is the quality of life in T2DM patients in hospital environment. The research methods were retrospective, frequency analysis, life quality assessment by a nonspecific SF-36 questionnaire. The pharmacoeconomic research included 2 groups of patients: the first group (25 patients) received the combination of metformin+gliclazide ( $43.1 \%$ of cases), the second one (56 patients) received the combination of metformin + glimepiride (16\%). Patients did not significantly differ from all of the parameters analyzed, and it enabled to compare their quality of life. The life quality parameters were assessed by a nonspecific SF-36 questionnaire. When studying the life quality in patients with the metformin + gliclazide scheme the average physical health component was $24.64 \pm 0.63$ and the average mental health component was 25.24 \pm 0.78 ; in patients with the metformin + glimepiride scheme the average physical health component was $23.89 \pm 1.1$ and the average mental health component was $24.37 \pm 0.55$. These results indicate that the quality of life in patients is fairly low and does not depend on the pharmacotherapeutic scheme used, obviously it is due to the severity of the T2DM course and the presence of complications. The quality of life in patients according to the physical and mental components has fairly low indicators irrespective of the pharmacotherapeutic scheme used.
\end{abstract}

At present diabetes mellitus (DM) acquires the status of non-infectious epidemic that affects all society. DM complications reduce the parameters of the life quality of patients significantly and constitute the greatest danger [5].Taking into account that the last World Health Organization programme activities are directed to improvement of the life quality of patients by improving the quality of diagnosis and treatment of chronic diseases [4] the need to study the quality of life in clinical practice, in particular in endocrinology, becomes clear. Today the life quality assessment is a promising direction of medicine which allows to determine a reasonable method of treatment [1].

The aim of this study is the use of SF-36 questionnaire for determining the quality of life of patients with T2DM when applying different schemes of pharmacotherapy.

The research objectives are:

1) carrying out retrospective analysis of medical histories and treatment sheets of T2DM patients in hospital environment;

2) carrying out frequency analysis of the treatment regimens used;

3) analysis of the patients included in the study according to certain parameters (age, gender, body mass index (BMI), fasting plasma glucose (FPG) on admission, duration of disease of T2DM) in the context of drug regimens;

4) carrying out survey of T2DM patients in hospital environment by a nonspecific SF-36 questionnaire;

5 ) determination of the quality of life in patients with the most commonly used treatment regimens.

The research object is the quality of life in T2DM patients in hospital environment.

The research methods are:

1. retrospective analysis;

2. frequency analysis;

3. the life quality assessment by a nonspecific SF36 questionnaire.

\section{Materials and Methods}

To select the most frequently used drug regimens the frequency analysis of all (599) medical histories and treatment sheets of T2DM patients included in this study was conducted. Selection of treatment regimens was carried out by endocrinologists. All patients treated in 2011-2012 in the Vinnytsia Regional Clinical Endocrinology Clinic (VRCEC) were included in the study.

As a result of frequency analysis it was found that the following schemes of pharmacotherapy were the most frequently used: metformin+glimepiride in $43.1 \%$ 


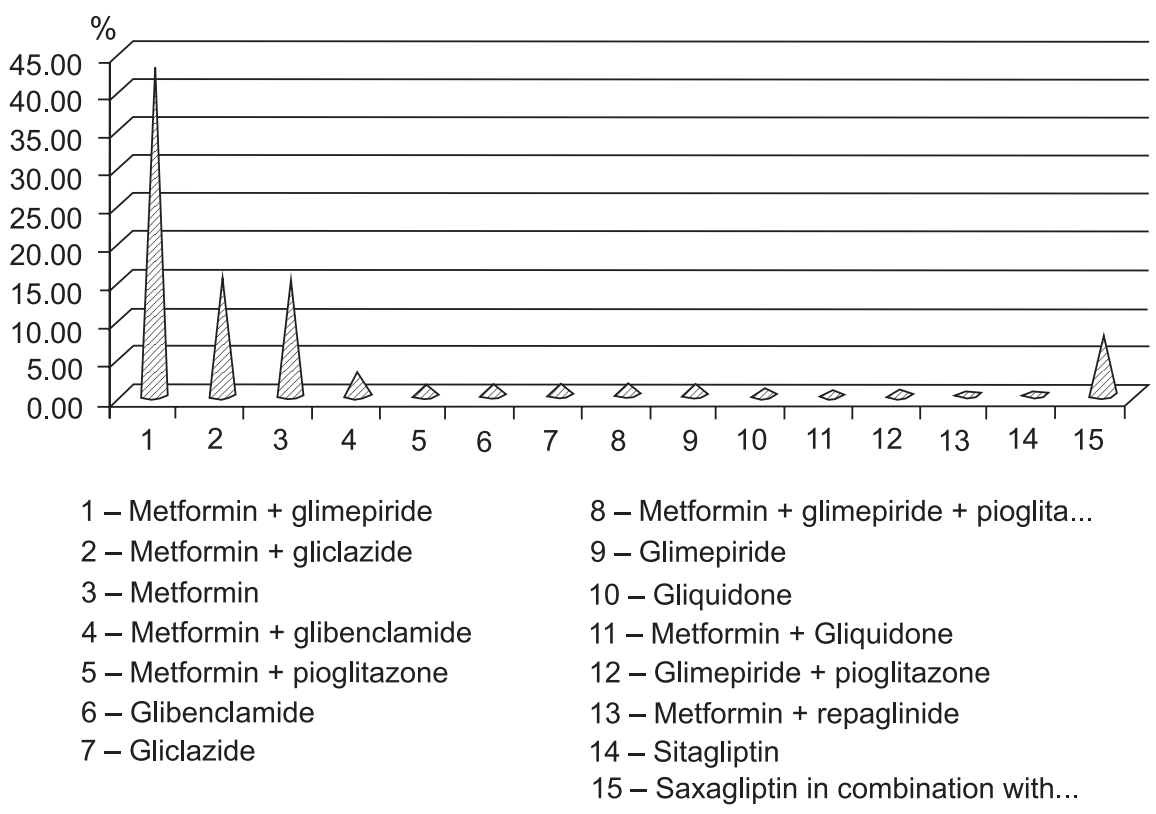

Fig. Frequency analysis of the treatment regimens of T2DM patients in VRCEC.

of cases, gliclazide + metformin - in $16 \%$ of cases, metformin monotherapy - in $15.5 \%$ of cases. Treatment was applied for all patients according to the state standard for management of T2DM patients [8], including monotherapy and combination therapy. The above pharmacotherapy schemes were used for 445 patients. Other 144 patients received various pharmacotherapeutic schemes at a frequency from $0.2 \%$ to $8 \%$ (Figure).

The pharmacoeconomic research included 81 patients on the combined pharmacotherapy: the first group (25 patients) received the combination of metformin + gliclazide, the second one (56 patients) received the combination of metformin + glimepiride.

Patients of the first and second groups received different pharmacotherapy and did not significantly differ by all of the parameters analyzed, and it enabled to compare their quality of life in the context of the treatment schemes selected (Tab. 1).

There were 41 men and 40 women among the respondents, the average age was $57.9 \pm 0.87$ years (from 35 to 76 years old). All patients had complications of T2DM. For example, in the $1^{\text {st }}$ group retinopathy was observed in $66.7 \%$ of patients, angiopathy - in $98 \%$, neuropathy - in 97\%, nephropathy - in 19\%, cardio- vascular complications - in $83 \%$. In group 2 of patients retinopathy was found in $45 \%$, neuropathy - in $91 \%$ angiopathy - in $88.8 \%$, nephropathy - in $17.4 \%$, cardiovascular complications - in $91.5 \%$. All patients received treatment according to standard management of patients with T2DM [2].

Parameters of the life quality of patients were assessed by a nonspecific SF-36 questionnaire recommended by Ware J.E., Kosinski M., Keller S.D. Statistical analysis of information was carried out by means of the instructions prepared by Evidens company that deals with clinical and pharmacological investigations $[3,7]$. A nonspecific SF-36 questionnaire was adapted for the study groups of patients with different chronic diseases $[6,8]$.

Questions of the questionnaire were grouped into eight scales. The scales were grouped into two indicators "physical health component" and "mental health component". The physical health component scale includes the following items: physical functioning, rolephysical functioning, body pain, general health. As for the mental component of health it includes the following items: vitality, social functioning, role-emotional, mental health. Indicators of each scale vary between 0

Table 1

Characteristics of patients at different pharmacotherapeutic regimens

\begin{tabular}{|l|c|c|c|}
\hline \multirow{2}{*}{ Indicators } & \multicolumn{2}{|c|}{ Pharmacotherapeutic schemes } & \multirow{2}{*}{$\begin{array}{c}\text { The significance } \\
\text { of differences }\end{array}$} \\
\cline { 2 - 3 } & $\begin{array}{c}\text { Metformin + gliclazide } \\
\text { Scheme 1 }\end{array}$ & $\begin{array}{c}\text { Metformin + glimepiride } \\
\text { Scheme 2 }\end{array}$ & \\
\hline The number of patients & 25 & 56 & $\mathrm{p}>0.05$ \\
\hline Age (years) & $60.58 \pm 0.85$ & $59.30 \pm 0.53$ & $\mathrm{p}>0.05$ \\
\hline Gender (woman/man, \%) & $51 / 45,53 / 47$ & $142 / 116,55 / 45$ & $\mathrm{p}>0.05$ \\
\hline BMI (kg/m²) & $30.75 \pm 0.38$ & $31.65 \pm 0.33$ & $\mathrm{p}>0.05$ \\
\hline FPG when admission (mmol/L) & $11.39 \pm 0.34$ & $11.12 \pm 0.19$ & \\
\hline Duration of the disease (years) & $9.60 \pm 0.74$ & $8.42 \pm 0.35$ & $100 \%$ \\
\hline Complications & $100 \%$ & & \\
\hline
\end{tabular}


Table 2

Evaluation of the general health

\begin{tabular}{|l|c|c|c|c|c|}
\hline \multirow{2}{*}{ Statements } & \multicolumn{5}{c|}{ Answers (\% of patients) } \\
\cline { 2 - 6 } & $\begin{array}{c}\text { certainly } \\
\text { correct }\end{array}$ & $\begin{array}{c}\text { basically } \\
\text { correct }\end{array}$ & I don't know & $\begin{array}{c}\text { basically } \\
\text { incorrect }\end{array}$ & $\begin{array}{c}\text { certainly } \\
\text { incorrect }\end{array}$ \\
\hline $\begin{array}{l}\text { a) I think I'm more prone to } \\
\text { disease than others }\end{array}$ & 28 & 40 & 28 & 4 & 0 \\
\hline $\begin{array}{l}\text { b) my health is not worse than } \\
\text { most of my friends have }\end{array}$ & 23 & 60 & 13 & 3 & 0 \\
\hline $\begin{array}{l}\text { c) I am waiting for my health } \\
\text { deterioration }\end{array}$ & 47 & 50 & 2 & 0 & 0 \\
\hline d) I have excellent health & 0 & 1 & 1 & 53 & 45 \\
\hline
\end{tabular}

and 100, where 100 represents full health. All scales form two final indicators - the physical component of health and the mental component of health. The results are presented as score: a higher score indicates a higher level of the life quality.

\section{Results and Discussion}

When assessing the physical health component regardless of the treatment regimen the following information has been found:

1. physical functioning is "greatly limited" in $61 \%$ of patients (49 patients), "slightly limited" in 35\% of patients (28 patients), "not limited" only in $4 \%$ of patients (3 patients);

2. role-physical functioning "causes difficulties" in $82 \%$ of patients (66 patients), "do not cause difficulties" in $18 \%$ of patients (15 patients);

3. characteristics of pain by

a) pain intensity:

$27 \%$ of patients (22 patients) have a "very strong pain", the pain of 29\% (23 patients) is "strong", 17\% (14 patients) - "moderate pain", 17\% (14 patients) "weak pain", the pain of $10 \%$ of patients ( 8 patients) is "very weak" and there are no patients who do not feel pain at all;

b) pain prevents to do the usual work:

"very much" $-38 \%$ of patients (31 patients), "strongly" $-27 \%$ of patients (22 patients), "moderately" $-24 \%$ of patients (20 patients), "little" - 10\% (8 patients), pain "does not disturb" only $1 \%$ of patients (1 patient);

4. the general state of health is assessed by:

a) the opinion of the patient about his health:

$41 \%$ of patients (33 patients) define it as "poor", $43 \%$ of patients (35 patients) - as "moderate", 15\% of patients (12 patients) - as "good", $1 \%$ of patients (1 pa- tient) - as "very good", no patient defines his state as "excellent";

b) the patients' attitude to certain statements about health (Tab. 2).

When assessing the general state it has been found that $68 \%$ of patients (55 patients) suggest to be "more prone to disease than others"; $83 \%$ of patients (67 patients) consider "their health is not worse than in most of their friends"; $98 \%$ of patients (79 patients) are "waiting for health deterioration" and $98 \%$ of patients (79 patients) consider the statements about their "excellent health" to be "incorrect" (Tab. 2).

Thus, the study has shown that physical functioning is "greatly limited" in $61 \%$ of patients (49 patients); role functioning "causes the difficulties" in $82 \%$ of patients (66 patients); "very strong" and "strong" pain is felt by $56 \%$ of patients (45 patients); in 65\% (53 patients) pain "prevents the regular work"; $41 \%$ of patients (33 patients) have reported that their health is "poor"; $98 \%$ of patients (79 patients) expect "health deterioration" and consider the statement about their "excellent health" to be "incorrect".

When assessing the mental health component the vitality, social functioning, role-emotional and mental health were studied. In the study of vitality it has been found that $70 \%$ of patients (57 patients) "are rarely vigorous", $73 \%$ of patients (59) "rarely feel full of strength and energy", $88 \%$ of patients (71 patient) "always feel exhausted" and $89 \%$ of patients (72 patients) "always feel tired" (Tab. 3).

The study of social functioning has shown that in $27 \%$ of patients (22 patients) "their physical and emotional state is very serious obstacle to spend time with the family"; in $29 \%$ of patients (24 patients) it hin-

Table 3

Evaluation of the mental health component

\begin{tabular}{|l|c|c|c|c|c|c|}
\hline \multirow{2}{*}{ Questions } & \multicolumn{5}{c|}{ Answers (\% of patients) } \\
\cline { 2 - 8 } & all the time & $\begin{array}{c}\text { most of the } \\
\text { time }\end{array}$ & often & sometimes & seldom & never \\
\hline Did you feel vigorous? & 1 & 7 & 7 & 15 & 32 & 38 \\
\hline Did you feel full of strength and energy? & 1 & 5 & 3 & 18 & 62 & 11 \\
\hline Did you feel exhausted? & 41 & 47 & 7 & 2 & 3 & 0 \\
\hline Did you feel tired? & 52 & 37 & 3 & 2 & 5 & 1 \\
\hline
\end{tabular}


Evaluation of Mental Health

\begin{tabular}{|l|c|c|c|c|c|c|}
\hline \multirow{2}{*}{\multicolumn{1}{|c|}{ Questions }} & \multicolumn{7}{c|}{ Answers (\% of patients) } \\
\cline { 2 - 8 } & all the time & $\begin{array}{c}\text { most of } \\
\text { the time }\end{array}$ & often & sometimes & seldom & never \\
\hline Are you very nervous? & 18 & 43 & 18 & 11 & 10 & 0 \\
\hline $\begin{array}{l}\text { Did you feel so depressed that nothing } \\
\text { could encourage you? }\end{array}$ & 27 & 40 & 16 & 9 & 7 & 1 \\
\hline Did you feel calm and tranquility? & 1 & 11 & 8 & 20 & 55 & 5 \\
\hline Were you depressed with low spirit and sad? & 40 & 44 & 5 & 3 & 8 & 0 \\
\hline Did you feel happy? & 0 & 3 & 7 & 5 & 70 & 15 \\
\hline
\end{tabular}

ders "very much"; in $34 \%$ of patients ( 28 patients) it interferes "moderately"; in 9\% of patients (7 patients) it "bothers a little"; in 1\% of patients ( 1 patient) - "it doesn't bother at all". The physical and emotional health prevents from active communication with people "all the time" in $38 \%$ of patients ( 31 patients), "most of the time" $-47 \%$ of patients ( 38 patients), "sometimes" $12 \%$ of patients ( 10 patients), "rarely" $-3 \%$ of patients ( 2 patients), "never" $-0 \%$ of patients ( 0 patients).

The study of role-emotional functioning has shown that "there are difficulties in usual daily activities" in $86 \%$ of patients (70 patients), "there are no difficulties" - in $14 \%$ of patients (11 patients).

Analysis of the mental health has found that $79 \%$ (64 patients) are "very nervous all the time", 67\% (54 patients) "feel depressed all the time", 75\% (61 patients) "rarely feel calm" and 85\% (69 patients) are "have never been happy" (Tab. 4).

Hence, it has been found that $70 \%$ of patients (57 patients) "are seldom vigorous"; "the physical and emotional health interfers to spend time with the family very much" in $56 \%$ of cases ( 45 patients) and "actively communicate with people most of the time" in $85 \%$ of patients (69 patients); role functioning "causes difficulties in usual daily activities" in $86 \%$ of patients (68 patients); 79\% (64 patients) are "very nervous all the time"; $67 \%$ (54 patients) "feel depressed all the time".
In the study of the quality of life in patients with pharmacotherapeutic scheme 1 the average physical health component was $24.64 \pm 0.63$ and the average mental health component was $25.24 \pm 0.78$; in patients with pharmacotherapeutic scheme 2 the average physical health component was $23.89 \pm 1.1$ and the average mental health component was $24.37 \pm 0.55$.

Thus, these results indicate that the quality of life in patients is fairly low and does not depend on the pharmacotherapeutic scheme used, obviously it is due to the severity of the T2DM course and the presence of complications.

\section{CONCLUSIONS}

1. It has been found in frequency analysis that among the patients included in research the following schemes of pharmacotherapy are used the most frequently: metformin + glimepiride in $43.1 \%$ of cases and gliclazide + metformin in $16 \%$ of cases.

2 . When comparing groups of patients received different pharmacotherapy it has been found that patients do not significantly differ from all of the parameters analyzed.

3. The survey conducted among 81 patients by SF36 questionnaire has revealed the low indicators of the life quality of patients according to the physical and mental components irrespective of the pharmacotherapeutic scheme used.

\section{REFERENCES}

1. Воробьев П.А., Авксентьева М.В., Борисенко О.В. и др. Клинико-экономический анализ. Изд. 3-е, доп. с приложениями. - М.: Ньюдиамед, 2008. - 778 с.

2. Наказ Міністерства охорони здоров'я України від 22.05.2009 №356 «Протокол надання медичної допомоги хворим на неускладнений иукровий діабет».

3. Новик А.А., Ионова Т.И. Руководство по исследованию качества жизни в медицине. - М.: ОЛМА меduazpynn, 2007. $-314 c$.

4. Стаценко М.Е., Щербакова Т.Г., Осипова А.О. // Укр. мед. журн. - 2008. - №2 (64). - С. 61-65.

5. Ягудина Р.И., Куликов А.Ю., Аринина Е.Е. Фармакоэкономика сахарного диабета второго типа. - М.: ООО «Медицинское информационное агентство», 2011. - C. 63-66.

6. Barbieri M., Drummond M., Rutten F. et al. // Value Health. - 2010. - Vol. 13(8). - P. 1028-1037.

7. De Vries F.M., Denig P., Visser S.T. et al. // Value Health. - 2014. - Vol. 17(2). - P. 223-230.

8. Parker D., Bechinger-English, Jagger C. et al. // Age and Ageing. - 2006. - Vol. 35, №4. - P. 376-381.

9. Renee J.G.A. Pharmacoeconomics: From Theory to Practice (Drug Discovery Series) Roca Raton. - Fl. CRC Press, 2009. - P. 119-133. 
10. Walley T., Haycox A., Boland A. Pharmacoeconomics. - Elsevier Science, 2004. - P. 122-123.

11. www.idf.org

12. www.rand.org/health/surveys_tools/mos/mos_core_36item.html

13. therapy.irkutsk.ru/doc/sf36a.pdf

ОПИТНИК SF-36 ЯК ІНСТРУМЕНТ ОЦІНКИ ЯКОСТІ ЖИТТЯ ХВОРИХ НА ЦУКРОВИЙ ДІАБЕТ 2 типу

Т.А.Германюк, Т.І.Івко

Ключові слова: иукровий діабет; якість життя; фрармакотерапія; опитник SF-36

На теперішній день иукровий діабет (ЦД) істотно знижує параметри якості життя пацієнтів. Тому оцінка якості життя - актуальний та перспективний напрямок медицини, який дає можливість визначити обгрунтований метод лікування. Метою дослідження було використання опитника SF-36 для визначення рівня якості життя хворих з ЦД 2 типу при застосуванні різних схем фрармакотерапії. Завдання дослідження: 1) проведення ретроспективного аналізу листів призначень та історій хвороб хворих на ЦД 2 типу в стаціонарних умовах лікування; 2) проведення частотного аналізу вживаних схем лікування; 3) аналіз хворих, включених у дослідження; 4) проведення анкетування хворих на ЦД 2 типу; 5) визначення якості життя у хворих. Об’єкт дослідження: якість життя хворих на ЦД 2 типу. Методами дослідження були ретроспективний, частотний аналіз, оцінювання якості життя за допомогою неспецифрічного опитника SF-36. У фрармакоекономічне дослідження були включені 2 групи пацієнтів: перші (25 пацієнтів) отримували комбінацію меторормін + гліклазид (43,1\% випадків), другі (56 пацієнтів) - комбінацію метформін + глімепірид (16\%). Хворі достовірно не відрізнялися по всіх аналізованих показниках, що дало змогу порівнювати якість їх життя. Параметри якості життя оцінювали по неспецифрічному опитнику SF-36. При дослідженні якості життя у хворих зі схемою метформін + гліклазид фрізичний компонент здоров'я склав

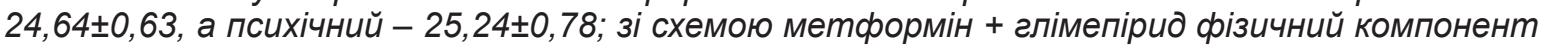

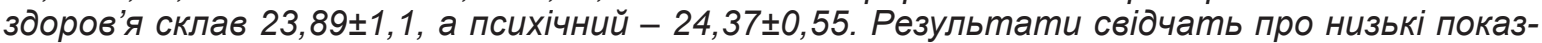
ники якості життя у хворих, які не залежать від вживаної схеми фрармакотерапії, вочевидь, обумовлені важкістю перебігу ЦД 2 типу та наявністю ускладнень. Якість життя хворих за фрізичним та психологічним компонентом, які мали низькі значення, не залежало від вживаної схеми фрармакотерапії.

\section{ОПРОСНИК SF-36 КАК ИНСТРУМЕНТ ОЦЕНКИ КАЧЕСТВА ЖИЗНИ БОЛЬНЫХ САХАРНЫМ ДИАБЕТОМ 2 ТИПА}

\section{Т.А.Германюк, Т.И.Ивко}

Ключевые слова: сахарный диабет; качество жизни; фрармакотерапия; опросник SF-36

Сегодня сахарный диабет (СД) существенно снижает параметры качества жизни пациентов. Поэтому оценка качества жизни - актуальное и перспективное направление медицины, позволяющее определить обоснованный метод лечения. Целью исследования было использование опросника SF-36 для определения уровня качества жизни больных с CД 2 типа при применении различных схем фрармакотерапии. Задачи исследования: 1) проведение ретроспективного анализа листов назначений и историй болезней больных СД 2 типа в стационарных условиях лечения; 2) проведение частотного анализа применяемых схем лечения; 3) анализ больных, включенных в исследование; 4) проведение анкетирования больных СД 2 типа; 5) определение качества жизни больных. Объект исследования: качество жизни больных СД 2 типа. Методами исследования были ретроспективный, частотный анализ, оценка качества жизни с помощью неспецифического опросника SF-36. В фрармакоэкономическое исследование был включено 2 группы пациентов: первые (25 пациентов) получали комбинацию метфоормин + гликлазид (43,1\% случаев), вторые (56 пациентов) - комбинацию метформин + глимепирид (16\%). Больные достоверно не отличались по всем анализируемым показателям, что дало возможность сравнивать качество их жизни. Параметры качества жизни оценивали по неспецифическому опроснику SF-36. При исследовании качества жизни у больных

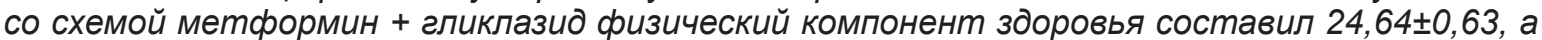
психический - 25,24 0,78 ; со схемой метфрормин + глимепирид физический компонент здоро-

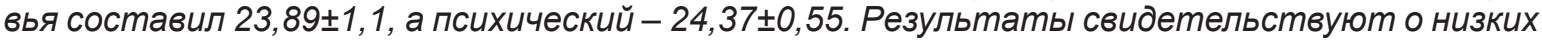
показателях качества жизни у больных, которые не зависят от применяемой схемы фрармакотерапии, очевидно, обусловленные тяжестью течения СД 2 типа и наличием осложнений. Качество жизни больных по фризическому и психическому компонентам имели низкие значения, независимо от применяемой схемы фрармакотерапии. 